\title{
Standing Against Injustice and Working Towards Reconciliation in Health Care
}

\author{
Jody Ciufo, Zack Dumont, Tania Mysak, Shirin Abadi, and Tamar Koleba
}

DOI: 10.4212/cjhp.v74i4.3203

The recent discoveries of unmarked graves with children's remains at former residential schools have shaken Canadians, and others around the world, to the core. As individuals, we must face the violence and injustice of colonialism in this country and recognize the intergenerational trauma of residential school survivors. We must stand with Indigenous peoples and act to end the ongoing discrimination and abuse.

As a professional association, how can the Canadian Society of Hospital Pharmacists (CSHP) stand up against injustice and work towards reconciliation in health care? This work begins with acknowledging the historic complicity of Canadian health care systems, which subjected Indigenous communities, including children in residential schools, to unethical medical experiments and testing (https://academic. oup.com/pch/article/19/2/64/2647158) for surgeries, drugs, and vaccines (https://www.cmaj.ca/content/193/11/E381).

In every province, the horrific legacy of colonialism continues in the institutional racism of our health care system today. In Saskatchewan, Indigenous women have reported experiencing coerced sterilizations as recently as 2019 (https://globalnews.ca/news/7920118/indigenous-womensterilization-senate-report/). In 2020, Joyce Echaquan died in a Quebec hospital after filming staff's racist abuse. In British Columbia, the 2020 "In Plain Sight" report found that $84 \%$ of the 9,000 Indigenous people taking part in the investigation had experienced discrimination while accessing health services (https://engage.gov.bc.ca/app/uploads/ sites/613/2021/02/In-Plain-Sight-Data-Report_Dec2020. pdf1_.pdf). Racism in health care is ubiquitous and deadly.

As a body of health care professionals, CSHP sees the grave harms the Canadian health care system has caused and continues to cause Indigenous peoples and people of colour. We recognize that we are accountable for changing the systems and institutions in which we work. The racism in our workplaces is unacceptable-the trauma, abuse, and indignity must stop.

The Board calls on CSHP members to join us in committing to fight systemic racism wherever we encounter it, whether it surfaces in the inequitable treatment of patients or in the barriers Black, Indigenous, or people of colour (BIPOC) pharmacists face in career advancement. This work will look different for each individual: completing an anti-racism training program, reporting discrimination when we see it, and advocating for Indigenous cultural safety through cultural humility are all important steps in making a meaningful difference (https://www.fnha.ca/ wellness/wellness-and-the-first-nations-health-authority/ cultural-safety-and-humility). The Truth and Reconciliation Commission's Calls to Action offers further ways we can work towards improving the quality of Indigenous health services, such as advocating for greater recognition of Indigenous healing practices and increasing Indigenous representation within the profession (https://ehprnh2mwo3. exactdn.com/wp-content/uploads/2021/01/Calls_to_ Action_English2.pdf).

Large or small, every action against systemic racism matters. In the coming months, CSHP's next steps include working to eliminate from use the racist term "Red Man Syndrome," and creating meaningful land acknowledgement guidelines for the Society. In these modest efforts, we commit to amplifying and centring the voices of Indigenous members. At the same time, we recognize that non-Indigenous allies must be accountable for the work of creating change. We hope you will share your voice and expertise with our community. Members who wish to help shape CSHP's antiracism work are invited to contact us at info@cshp.ca. Those with lived experience are especially encouraged to reach out if they feel safe and comfortable in doing so.

As pharmacy professionals, CSHP members are no strangers to facing complex challenges, seeking rigorous evidence, and advocating for and with those whom our culture makes vulnerable. Together, our community is wellequipped to fight for equity, and each one of us has a role to play in making racism in health care a relic of the past.

\footnotetext{
Jody Ciufo, MBA, is Chief Executive Officer of the Canadian Society of Hospital Pharmacists.

Zack Dumont, BSP, ACPR, MS(Pharm), is President and Internal Liaison for the Canadian Society of Hospital Pharmacists.

Tania Mysak, BSP, PharmD, is Past President and Vision Liaison for the Canadian Society of Hospital Pharmacists.

Shirin Abadi, BSc(Pharm), ACPR, PharmD, DPLA, MBA, FCSHP, RPh, is President Elect and External Liaison for the Canadian Society of Hospital Pharmacists.

Tamar Koleba, BSc(Pharm), ACPR, PharmD, is Treasurer of the Canadian Society of Hospital Pharmacists.
} 